\title{
The effect of e-WOM through intention to use technology and social media community for mobile payments during the COVID-19
}

\author{
Zeplin Jiwa Husada Tarigan $^{a^{*}}$, Michelle Jonathan ${ }^{b}$, Hotlan Siagian $^{a}$ and Sautma Ronni Basanab
}

${ }^{a}$ Master Management Department, Petra Christian University, Siwalankerto 121-131 Surabaya, Indonesia

${ }^{b}$ Management Department, Petra Christian University, Siwalankerto 121-131 Surabaya, Indonesia

\section{H R O N I C L E A B S T R A C T}

Article history:

Received: June 20, 2021

Received in revised format: September 20, 2021

Accepted: November 19, 2021

Available online: November 19, 2021

Keywords:

Ease of use

$e-W O M$

Intention to use technology

The social media community

\begin{abstract}
The use of mobile payments has become a public interest during the current spread of the coronavirus. The use of mobile payments prevents society from touching the payment media. This study examines the effect of ease of use on e-WOM through the intention to use and social media community on the mobile payment method. This research was conducted by taking data through closed questionnaires designed with a five-point Likert scale. This study distributed two hundred fifty questionnaires, and 202 returned to be processed using the partial least square (PLS) technique. The results of data processing show that the ease of use of technology applications had a positive effect on the intention to use an e-WOM. Ease of use of technology has a positive effect on the social media community because of the ease of operation and understanding of the steps for using technology to access and join as members of the social media community. Intention to use in the operation of technology and relatively low cost does not directly affect e-WOM but must go through a community on social media that provides an exciting atmosphere. The social media community has a significant effect on e-WOM. The social media community can share information on social media and share reviews between members so that it creates a sense of trust and mutual concern among members. This study provides an insight into the mobile payment provider to consider the ease of use of their design. This research contributes to the ongoing research in the online payment application study in the pandemic era.
\end{abstract}

\section{Introduction}

The use of mobile payments as a means of making payments has attracted public interest because it provides convenience, practicality, and security (Kavitha and Kumar, 2018). The growth in the use of mobile payments does not only occur in Indonesia but various countries. The use of mobile payments will increase in 2020 due to an increase in the number of Covid19 infected. The spread of the viruses is due to contact between a COVID sufferer through a medium that can transmit, including the use of work media, payment media for transportation media, and other media that have been contaminated and then touch the eyes, nose, or mouth (WHO, 2020). The government also advises residents to make a payment system that is safe from the coronavirus by not making payments directly to prevent the spread of the virus. Currently, the digital platform has been running well and has provided facilities related to mobile payments, including Gojek, Gojek, Tokopedia, Bukalapak, Halodoc, Lazada, and Ruangguru, which have provided facilities and support (Djalante, 2020).

The growth rate of mobile payment users in various countries is quite large. The highest development of mobile payment users in China reached 86\% in both 2018 and 2019. The growth of mobile payment users in Indonesia in 2018 reached $38 \%$,

* Corresponding author.

E-mail address: zeplin@petra.ac.id (Z. J. H. Tarigan)

(C) 2022 by the authors; licensee Growing Science, Canada. doi: $10.5267 /$ j.ijdns.2021.11.008 
and the growth in 2019 reached 67\%. Various factors can cause the enormous growth of mobile payment users, and one of them is eWOM. Sahin, Gulmez, and Ersoy (2019) stated that e-WOM is information communicated between consumers about a product and is carried out voluntarily through an electronic network. Information between consumers is relatively trustworthy because consumers who provide information do not tend to benefit as when the company provides the information. EWOM has a strong influence on consumer behavior because e-WOM has a positive influence on consumer trust in a brand (López and Sicilia, 2013). E-WOM affects trust in a brand because when providing information about a product or service, it is another consumer who is not paid by the company, the consumer will have more confidence in the information in e-WOM. Information technology can accelerate the process of communication and sharing of data between supply chains in the business (Tarigan et al., 2021).

The critical role of e-WOM in marketing is the orientation of the company to build a positive e-WOM so that it supports marketing activities (Terenina et al., 2019). E-WOM, which has a positive meaning, is influenced by various variables: ease of use, web design, responsiveness, personalization, and assurance (Anita, 2019). These five dimensions affect e-WOM because when consumers are satisfied with the five dimensions, they cause consumers to share information via electronic media. Based on the object under study now, namely mobile payment, from the five dimensions related to mobile payment, namely ease of use. The definition of mobile payment, as stated by Aydin and Burnaz (2016), is a payment process for transactions of goods, services, or other bills made using mobile communication and devices. Ease of use of an application or website affects e-WOM because when an application is easy to use, it causes the user to feel satisfied, and this satisfaction encourages him to inform other consumers. Meanwhile, other variables are web design, responsiveness, personalization, and assurance in research conducted by Anita (2019) for hotel websites, so that website design, responsiveness, personalization, and assurance are related to hotel services while in this study more focus on applications.

A strong e-WOM is also influenced by the high use of social media, even based on this source, it is stated that such information is transformed to other consumers in social media. For this reason, the high use of social media encourages the strengthening of e-WOM because e-WOM occurs from the use of social media. Indonesian people are cultured to gather and socialize, but due to time constraints, the community on social media is in great demand by the public. Community members on social media can socialize and interact in cyberspace even though they cannot meet in person. The benefit of the community on social media makes many groups of people interact with each other (for example, because of regional backgrounds, family, education alumni, and others) to build communities on social media to interact with each other. The use of community in social media encourages the occurrence of e-WOM because the original purpose of these communities was formed to be able to interact with each other (Choi et al., 2017).

The use of social media for consumers varies, and many of them are by building online communities. This community takes various forms, both communities related to hobbies, communities related to work, communities related to professions, and communities related to brands. The critical role of this community causes many companies to be interested in building a community to support product marketing (Vohra and Bhardwaj, 2019). E-WOM, as research by Mensah (2010), is also influenced by the intention to use technology, meaning that when consumers have a firm intention to use technology, especially social media technology, there is a tendency for consumers to share information and access information so that the intention to use technology affects e-WOM. Intention to use causes someone to take a long-time using technology, including social media technology, so that users tend to follow various information on social media by responding or providing information that they want to share with fellow community members. Meanwhile, according to Kumar et al. (2017), intention to use technology is also influenced by the ease of use. The findings explain that if consumers find it easy to use technology, there is a strong intention to use the technology for various consumer interests. This study aims to obtain the magnitude of the influence of ease of use on e-WOM through the intention to use technology and the social media community for mobile payment usage.

\section{Literature Review of E-Payment}

Electronic payment is payment via an electronic signal that is directly or indirectly related to a credit account (Lok et al., 2015). The electronic payment system is online-based and involves using a credit account. The credit account is created by the consumer through a financial company and fills in the balance in the credit account so that it can be used to make electronic payments. The e-payment system, as stated by Terenina et al., (2019), is also called a digital payment system. The definition given of electronic payment systems is a method of payment made using digital mode. The payment process is carried out by involving applications or internet media and does not use cash in cash. E-payment system is a payment system that involves three essential components, namely: partners, the technology, and the environment (Teoh et al., 2013). E-payment systems tend to be responded positively by the public, as stated by Kavitha and Kumar (2018), security and convenience in the payment process. The E-payment system provides security because it does not involve the use of cash so that the security factor can be maintained. The e-payment system is considered to reduce security risks because payment for a transaction is made online and does not involve the use of cash. The e-payment system also provides convenience because it saves time, and the process runs faster. The advantages to citizens of a county in a cashless economy are risk of carrying currency notes and loss of hardearned money can be avoided (Thirupathi et al., 2019). This opinion focuses more on the risk factors that are considered an 
advantage of an e-payment system because by using this payment system, the risk of losing money is lower. Unlike the case when payments are made physically, the possibility of security risks and risks of loss is more significant.

\subsection{Mobile payment}

Mobile payment is a payment process for transactions of goods, services, and other bills using mobile communication and devices (Aydin and Burnaz, 2016). This opinion reveals that mobile payment is defined as a payment service that involves the use of mobile communication and devices. Payment service that utilizes wireless with an application is specifically designed for online payments. The applications used have been designed with due regard to safety and comfort factors in their use. Mobile payment is a service that provides added value to users because it can be done by utilizing applications organized by mobile application service providers, mobile operators, and financial institutions. Based on mobile payment, it is a service for payments that involve device providers, cellular operators, and financial institutions in a device so that users can make payments (Teoh et al., 2013).

\subsection{Ease of use}

Ease of use of technology as a person's level of confidence in using a technology that only requires a little effort (Lok, 2015). The purpose of this opinion is the ease of using a media or technology if someone is not required to have specific criteria that make it difficult to use the media or technology. Someone feels they do not need excessive energy or effort to be able to use a technological application. The meaning of ease of use is also relatively the same as stating that ease of use is one's belief that the use of a particular system does not require significant effort (Correa et al., 2019). The use of a specific technology requires an understanding of navigation or certain ways, but when a respondent believes that a method is standard, it means that the level of ease of use from the use of technology is high. Ease of use is stated as the level of one's confidence as a user of a particular system (Lok, 2015). When a system user can improve performance, ease of use is declared high. Perceived ease of use refers to their perceptions regarding the process leading to the outcome.

Ease of use of technology leads to the perception of the process to produce the final result, meaning that when the result of a job increases, it means that the ease of use of the technology used is high (Terenina et al., 2019). The ease of use of technology as usability, which is the ability of a technology to be used (Basuki et al., 2022). High usability means the technology is easier to use, and there are no significant barriers from users on technology. The characteristics of the stability of a product or technology application include seven characteristics, including navigation, familiarity, consistency, error prevention, feedback, visual clarity, and flexibility \& efficiency. Indicators of ease of use are adopted (Shaw \& Kesharwani, 2019), which include four indicators, namely: ease of becoming proficient in operating technology applications, ease of operation of technology applications, ease of operating steps for technology applications, and ease of interaction with technology applications.

\subsection{Intention to use technology}

Intention to use technology is defined as a measure of the likelihood that a person will employ the application (Yalcin \& Kutlu, 2019). This opinion reveals that the intention to use technology is assessed as the level of possibility for someone to use an application. The intention is understood as a desire or intention, so that intention to use technology is considered a form of the possibility that will be carried out by technology application users. A firm intention to use technology means that the possibility of using the application is also greater. Intention to use technology is the attitude and trust of technology users to use an application because it is based on desire or desire. Intention to use technology is related to positive attitudes and behaviors to accept a technology application and tend to use it (Basuki et al., 2022). Intention to use technology is a commitment from within a person to use an application. The intention to use technology for technology is based on the attractiveness of a technology (Sathye et al., 2016). This attraction provides a stimulus to a person's intention to try to describe a technological application. The strength and weaknesses of the intention to use technology are determined by a person's perception of the technology benefit. A technology application that provides high benefits causes the intention to use technology for this technology application is also getting higher.

Intention to use technology is a technology acceptance model (TAM) concept, and intention to use technology is influenced by ease and usefulness, meaning that when a technology application is assessed by someone easy to operate and has high benefits, the intention to use technology is also high (Yalcin \& Kutlu, 2019). Ease and expediency indicate the level of convenience and usability so that it affects the strength and weakness of the intention to use technology. Measurement indicators for intention to use technology are based on research indicators by Sathye et al., (2016). Four indicators measure the intention to use technology, namely a strong tendency to use technology applications, there is an opportunity to allow for other uses but still use technological applications, the tendency to keep using technology applications because of the relatively cheap rates, and the tendency to keep using technology applications quickly. 
Social media is an internet application-based group that allows exchanges between users of these internet-based applications. Social media is understood as an internet-based application, and users can interact with each other, not only in the form of visuals (images) and audio (sound) but also in the form of content (Voorveld et al., 2018). Social media communities are also called virtual communities. A virtual community is a community built on social media networks, and there is a membership system by submitting as a member of a community and the admin of the social media community who has the right to accept or reject membership (Hsu et al., 2016). Membership in the social media community can share and access information in that community (Vohra \& Bhardwaj, 2019). The social media community is the use of the internet to participate in a community and feel a sense of belonging to the community, and there is trust between community members and can share information and needs in the community (Basuki et al., 2022). The community is considered as an association, and the association is built-in online media. Associations are usually built because of a similarity with different backgrounds.

Social media community members bond with other members. Social media and the community on social media, and someone has certain expectations with the existence of social media, causing interaction to occur between users. Being a member of the social media community shows that members have similarities to one another, and this also shows differences from other communities. Each member can be involved and have a role in emotional involvement so that they are able to share sadness, happiness, hatred, pride which are considered effective in providing information or knowledge to members (Tarigan et al., 2020). Based on knowledge and someone has confidence in the social media and social media community led to their relationship. This relationship is more profound than interaction. A social media community is based on the goals that someone wants to achieve, and someone also feels value by being involved in social media, which causes engagement (Cabosky, 2016). The indicators used to measure the social media community are based on the research indicators in Hsu et al., (2016) which are based on thirteen (13) indicators as follows: have His expertise in social media has earned him a lot of praise, being part of the social media community, comfortable being a member of the social media community, being a member of the community on social media, as a member of the community on social media has contributed a lot, the community in social media as a separate place, like the community on social media, the social media community in it has a significant meaning, community members on social media become friends, are able to get to know the names of members in the social media community, are able to present particular issues in the social media community to be discussed, there is concern and response of other members to something that is done and the social media community can Don't affect the other members.

\subsection{Electric word of mouth (e-WOM)}

E-WOM marketing is the way professional marketing techniques intentionally influence consumer-to-consumer communications (Sahin et al., 2019). This opinion reveals that e-WOM is a professional marketing technique involving consumer participation. Information about products that consumers provide to other consumers is called e-WOM. E-WOM is considered as a company strategy because it is beneficial for the marketing aspects of the company as long as the WOM is positive, that is, the information communicated between consumers is positive information about the product (Terenina et al., 2019). E-WOM is information or issues that are shared between individuals via electronic networks. Marketing activities can be used in the context of digital communication by conveying positive and negative things to customers as a form of confirmation of a product (. E-WOM is based on information or issues shared in electronic media, and this electronic media has a broad scope, which can be through social media, mobile features such as SMS, shared via WhatsApp, line, and others (Elsabeh et al., 2019). WOM is a face to face conversation between consumers about products or experiences on services, but the notion of e-WOM does not have to be face to face. It does not have to coincide because e-WOM can be done through someone's opinion written in Internet media and can last for a long time, and from these opinions will emerge a variety of responses. e-WOM occurs between consumers, but among these consumers with different positions regarding information dissemination (López and Sicilia (2014, p.29).

The consumer whose position is to provide information is called the source, and the consumer who receives the information is called the receiver. Although the positions are different, namely as a source and recipient of information, reciprocal communication occurs between the two. The difference between WOM and eWOM lies in the absence of media between the two parties, and e-WOM occurs when communication between the source and receiver is via the internet. Indicator of e-WOM described by Sahin et al., (2019) and to share various information like social media, share a wide range of the latest information about a variety of things in social media, share a variety of information deemed of interest in social media, trust in information shared on social media that it is a real experience, various reviews provided by other consumers are more trustworthy, pay more attention to recommendations given by social media communities that have many members, share information about 
the promotion of a product in social media, and shares from friends on social media are more interesting than information in newspapers or magazines, and various information about products shared on social media affects purchasing decisions.

\subsection{The relationship between concepts}

Ease of use of a technology application influences e-WOM. Technology application users who feel that there is the ease in the operation of this technology cause a sense of pleasure and satisfaction, which encourages them to share various information on social media (Anita, 2019). The pleasant experiences of a technology application cause someone to be encouraged to inform other consumers, and the ease of internet access causes the information to be shared through the media. e-WOM occurs when consumers can access the internet. Various conveniences to use internet technology encourage consumers to use it, so they are involved in the process of e-WOM (Srivastava and Sharma, 2017; Cataluna et al., 2014).

Ease of use affects technology intention because when consumers find it easy to use technology, there is a strong urge to use this technology for various consumer interests (Lok et al., 2015). The results of research by Kumar et al., (2017) show that ease of use has a positive effect on the intention to use technology, meaning that when the level of ease of using high technology causes consumers to tend to use technology and when the level of ease of use of technology is low it also causes consumers reluctant to use it. The found findings regarding the effect of ease of use on the intention to use technology, where consumers find it easy to operate or negotiate a technology (Chinomona, 2013). The ease of use did not impact the increasing intention to use technology on perceived usefulness (Shaw and Kesharwani, 2019). It causes a strong impetus to take advantage of technology by using it.

Ease in the use of technology also encourages consumers to use the social media community. The ease of using social media encourages consumers to access the social media community because, with this convenience, consumers find it easy to socialize in the social media community (Elkaseh et al., 2016). The knowledge that consumers have is mainly related to the use of technology so that consumers find it easy to use technology encourages consumers to use social media communities (Chu and Kim, 2018; Wirtz and Gottel, 2016). The various benefits obtained from the social media community cause consumers to take advantage of them when they find it easy to use internet technology. Based on the relationship between these variables, the hypothesis is proposed as follows:

$\mathbf{H}_{1}$ : Ease of use affects e-WOM.

$\mathbf{H}_{2}$ : Ease of use affects the intention to use technology.

$\mathbf{H}_{3}$ : Ease of use affects the social media community.

The strong desire to use technology encourages consumers to use the social media community (Mensah, 2010). The tendency to use technology causes consumers to be more attached to the social media community because the use of this technology causes consumers to feel more profitable when connected with the social media community, given that consumers easily share information and access information (Lok et al., 2015). Chu and Kim's research (2018); Wirtz and Gottel (2016) also found that related activities on social media are carried out by consumers when consumers can access and operate internet technology. The increasingly intensive use of the internet induces consumers to be further involved in using it, especially to access communities on social media because that way, consumers feel that they are getting social benefits and satisfaction (Tarigan et al., 2020). Based on the relationship between these variables, the fourth hypothesis is determined as follow:

\section{$\mathbf{H}_{4}$ : Intention to use technology affects the social media community.}

E-WOM is influenced by the intention to use technology, meaning that when consumers have a firm intention to use technology, especially social media technology, there is a tendency for consumers to share information and access information, so that the intention to use effects e-WOM (Mensah, 2010). The intense intention to use technology encourages consumers to share information and access information so that they feel that they get more benefits from their desire to use technology. The increasingly full intention to use internet technology encourages consumers to share information on social media actively (Srivastava \& Sharma, 2017; Cataluna et al., 2014). The stronger desire to use technology encourages consumers to use it to get social needs by socializing through sharing information on online media. Based on the relationship between these variables, the proposed fifth hypothesis is:

\section{H5: Intention to use technology affects e-WOM.}

The use of social media affects e-WOM (Choi et al., 2017) because, with e-WOM, much information is transformed to other consumers in social media. For this reason, the high use of social media encourages the strengthening of e-WOM because eWOM occurs from the use of social media (Lok et al., 2015). Research by Seo, et al., (2020); Susanto and Keni (2018) also found that the social media community influences e-WOM because when consumers join a social media account, they will get notifications when other members share information. This finding encourages consumers to access it so that they are involved in e-WOM. Based on the relationship between these variables, the following hypothesis is proposed: 
H6: Social media community affects e-WOM.

It has been described previously that ease of use affects the intention to use the technology (Kumar et al., 2017; Chinomona, 2013). The ease with which someone uses technology will give someone often for a long time and become a habit in using that technology. The ease of use of these technological facilities will make it easy for someone to provide and share information in the use of technology to other people who are deemed necessary to obtain information. Sharing of information provided to others using online technology tools and providing recommendations by adding something positive and negative based on the experiences that have been obtained. This situation can be declared as e-WOM. Besides, the intention to use the technology influenced the e-WOM (Mensah's, 2010; Srivastava and Sharma, 2017; Cataluna et al., 2014). Based on these arguments, this study postulated the seventh hypothesis as follows:

\section{H7: The intention to use technology mediates the influence of ease of use on the e-WOM.}

Furthermore, the previous discussion has also proposed that ease to use affects the social media community (Elkaseh, Wong, and Fung, 2016, p. 192; Chu and Kim's research, 2018; Wirtz and Gottel,(2016). The use of facilities provided by the social media community makes it easier for someone to use these social media. Adapt someone in using social media easily and requires a short time and get relatively many benefits for these users. A person will be able to share joyful experiences, sad experiences, angry experiences, hateful experiences and show pride through the social media community which will provide an atmosphere for the community. This atmosphere is influenced by someone's posts in the form of experiences and influencing other communities is an application of e-WOM. The social media community influences the e-WOM (Choi et al., 2017; Seo, Park, and Choi, 2020; Susanto and Keni, 2018). Hence the eight hypothesis is postulated as follows:

\section{H8: Social media community mediate the influence of ease of use on the e-WOM.}

\section{Research method}

This study used a quantitative causal research type. The causal research examines the relationship between the variables studied. This research examines the influence between the four research variables, namely: ease of use, intention to use, the social media community, and e-WOM. The population of this research is the people of Surabaya who use mobile payments for transactions of goods, services, or other bills made using mobile communication and devices (Aydin \& Burnaz, 2016). The current condition of Covid has an impact on the teaching and education system in higher education, which is held with an online system, so that an electronic survey can be carried out to determine student satisfaction, and other things also need to be carried out by surveys of social media users who have made transactions via e-WOM (Tarigan et al., 2019). The sample criteria are; minimum age is 17 years, have a mobile payment, and have used it for shopping at least twice in the period March 2020-July 2020. The data analysis used the partial least square (PLS) technique. The PLS technique analyzes the data to examine the inner and outer models. The outer model tests the validity and reliability of the indicators, while the inner model examines the hypothesis. Table 1 demonstrated the demographic characteristics of the respondents. Most of the respondents $(66.3 \%)$ are male as the men tend to find their food, drinking, or other needs more often outside so that there is a desire to find the ease of payment, such as mobile payments.

Table 1

Respondent Demographics criteria

\begin{tabular}{|c|c|c|c|}
\hline Description of & Respondent Criteria & Frequency & Percentage \\
\hline \multirow{2}{*}{ Gender } & Male & 134 & $66.3 \%$ \\
\hline & Female & 68 & $33.7 \%$ \\
\hline \multirow{5}{*}{ Respondent Age } & Less than 21 Years & 25 & $12.4 \%$ \\
\hline & 21-30 Years & 138 & $68.3 \%$ \\
\hline & $31-40$ Years & 24 & $11.9 \%$ \\
\hline & 40-51 Years & 14 & $6.9 \%$ \\
\hline & More than 51 year & 1 & $0.5 \%$ \\
\hline \multirow{5}{*}{ Respondents Occupation } & Student & 84 & $41.6 \%$ \\
\hline & Private Employees & 70 & $34.7 \%$ \\
\hline & Business owner & 29 & $14.4 \%$ \\
\hline & Housewife & 7 & $3.5 \%$ \\
\hline & Civil Servant & 12 & $6 \%$ \\
\hline \multirow{4}{*}{ Spending time payment } & Less than IDR 100,000 & 29 & $14.4 \%$ \\
\hline & IDR $100,000-300,000$ & 75 & $37.1 \%$ \\
\hline & IDR $300,001-500,0000$ & 45 & $22.3 \%$ \\
\hline & $>$ IDR500 thousand & 53 & $26.2 \%$ \\
\hline
\end{tabular}

The respondents also show that $80.7 \%$ of respondents are less than 30 years old. This finding shows that the use of mobile payment applications is in the productive age of fewer than 30 years. Productive age uses more technology applications such as applications mobile payment than other ages. Meanwhile, based on occupation, the student constitutes the largest percentage, reaching $41.6 \%$ as a user of the mobile payment followed by employees (34.7\%), and self-employed (14.4\%). Students 
prefer to use mobile payments due to several benefits such as cashback or discounts when using mobile payments. The expectation for cashback is interesting because, in general, students have limited financial resources because they are still students (López \& Sicilia, 2013). Besides, based on the amount of expenditure using, the respondents' expense IDR100-IDR300 (37.1\%) followed by above IDR 500,000 (26.2\%), IDR300, 000- IDR500,000 (of 22.3\%), and less than IDR 100,000 (14,4\%) using the application because of getting various promos provided by the application (Idris, 2019).

\section{Analysis and Results}

The discriminant validity is assessed using the Fornell-Lacker criterion value, as indicated in Table 2 . When the autocorrelation is higher than the correlation with other variables, it means that discriminant validity is met. Table 2 proved that all autocorrelation is more significant than the correlation with other variables, which means that all indicators of the variable are valid in terms of discriminant validity. Another assessment of the indicator is the reliability to find out the indicator consistency when the measurement is performed at different times. Reliability testing uses Cronbach's alpha and composite reliability values. As shown in Table 2, the Cronbach's alpha value of four research variables is between $0.702-0.918$. The Cronbach's alpha value is above 0.70 , so that all variables are considered reliable based on the Cronbach's alpha value. The composite reliability value of the four research variables is between $0.813-0.931$. The value of composite reliability is above 0.70 , so that all variables are declared reliable based on composite reliability (Hair et al., 2019).

Table 2

Fornell-Larcker criterion and reliability

\begin{tabular}{|c|c|c|c|c|c|c|}
\hline Variable of Research & $\begin{array}{c}\text { Ease of } \\
\text { Use }\end{array}$ & $\begin{array}{c}\text { Intention to } \\
\text { Use }\end{array}$ & $\begin{array}{l}\text { Social Media } \\
\text { Community }\end{array}$ & e-WOM & $\begin{array}{c}\text { Cronbach's } \\
\text { alpha }\end{array}$ & $\begin{array}{l}\text { composite } \\
\text { reliability }\end{array}$ \\
\hline Ease of use & 0.838 & & & & 0.702 & 0.813 \\
\hline Intention to use technology & 0.506 & 0.723 & & & 0.808 & 0.878 \\
\hline Social media community & 0.375 & 0.371 & 0.717 & & 0.789 & 0.856 \\
\hline e-WOM & 0.426 & 0.406 & 0.690 & 0.728 & 0.918 & 0.931 \\
\hline
\end{tabular}

The next analysis is to assess the inner model that examines the research hypothesis, and the testing result is shown in Fig. 1.

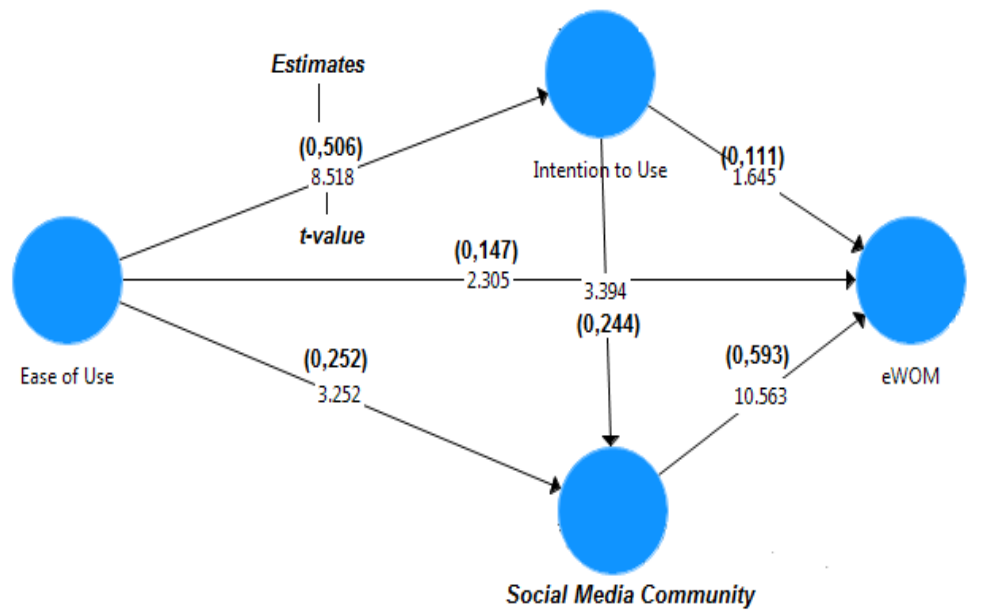

Fig. 1. Inner research Model

The results of hypothesis testing are shown in the following Table 3. Ease of use has been shown to have a significant effect on $e-W O M$, so that $H_{1}$ is accepted. The effect of ease of use on $e-W O M$ is positive so that the higher the assessment of ease of use causes, the stronger the $e-W O M$, and when the assessment of ease of use decreases, it causes a decrease in $e-W O M$.

Table 3

Result of hypothesis testing

\begin{tabular}{|c|c|c|c|c|}
\hline & Research Hypothesis & t- statistic $_{\text {. }}$ & requirement & remark \\
\hline $\mathrm{H}_{1}$ & Ease of use $\rightarrow$ eWOM & 2.305 & \multirow{8}{*}{ t-statistic $>1,96$} & supported \\
\hline $\mathrm{H}_{2}$ & Ease of use $\rightarrow$ intention to use technology & 8.518 & & supported \\
\hline $\mathrm{H}_{3}$ & Ease of use $\rightarrow$ Social media community & 3.252 & & supported \\
\hline $\mathrm{H}_{4}$ & Intention to use technology $\rightarrow$ Social media community & 3.394 & & supported \\
\hline $\mathrm{H}_{5}$ & Intention to use technology $\rightarrow \mathrm{e}-\mathrm{WOM}$ & 1.645 & & rejected \\
\hline $\mathrm{H}_{6}$ & Social media community $\rightarrow$ e-WOM & 10.563 & & supported \\
\hline $\mathrm{H}_{7}$ & Ease of use $->$ intention to use technology $\rightarrow$ e-WOM & 1.569 & & rejected \\
\hline $\mathrm{H}_{8}$ & Ease of use $->$ Social media community $\rightarrow$ e-WOM & 3.196 & & supported \\
\hline
\end{tabular}


The findings of this study supported the research that the stated ease of use of a technology application influences e-WOM (Anita 2019, Srivastava and Sharma, 2017; Cataluna et al., 2014). Technology application users who feel that there is an ease in the operation of this technology cause a sense of pleasure and satisfaction, which encourages them to share various information on social media. The pleasant experiences of using a technology application cause someone to be encouraged to inform other consumers, and the ease of internet access causes the information to be shared through the media. The research also explains that e-WOM occurs when consumers can access the internet.

Ease of use is proven to have a significant effect on the intention to use technology $\left(\mathrm{H}_{2}\right)$. The effect of ease of use on the intention to use technology is positive. The more ease to use technology implies stronger the intention to use technology, and when the ease of use decreases causes a decrease in intention to use technology. The findings supported the research by Kumar et al., (2017) and Chinomona (2013) stated that ease of use affects the intention of technology because when consumers find it easy to use technology, there is a strong urge to use this technology for various consumer interests.

Ease of use is proven to have a significant effect on the social media community so that $\mathrm{H}_{3}$ is supported. The influence of the ease of use on the social media community is positive so that the higher the level of ease to use enhances the existence of the social media community. These findings supported the research of Elkaseh et al., (2016); Chu and Kim (2018); Wirtz and Gottel (2016) stated that the ease of using social media encourages consumers to access the social media community because consumers find it easy to socialize in the social media community. The knowledge that consumers have is mainly related to the use of technology, causing consumers to feel comfortable using technology, encouraging consumers to use social media communities. The various benefits obtained from the social media community cause consumers to take advantage when they find it easy to use internet technology.

Intention to use technology is proven to have a significant effect on the social media community $\left(\mathrm{H}_{4}\right)$. A higher the intention to use technology causes a more robust existence in the social media community, and when the intention to use technology decreases causes a decrease in the social media community. The findings upported the research by Mensah (2010); Chu and Kim (2018); Wirtz and Gottel (2016) stated that a strong desire to use technology encourages consumers to use social media communities. The tendency to use technology causes consumers to be more attached to the social media community because the use of this technology causes consumers to feel more profitable when connected with the social media community, given that consumers easily share information and access information. The increasingly intensive use of the internet induces consumers to be further involved in using it, especially to access communities on social media because that way, consumers feel that they are getting social benefits.

Intention to use technology did not affect e-WOM $\left(\mathrm{H}_{5}\right.$ is rejected). The findings of this study are different from those of research by Mensah (2010) and Srivastava and Sharma (2017). Cataluna et al., (2014) explained that e-WOM is influenced by the intention to use technology, meaning that when consumers have a firm intention to use technology, especially social media technology, there is a tendency for consumers to share information and access information so that the intention to use technology affects e-WOM. The difference in the findings of this study with previous research is due to differences in the characteristics of research respondents, where current research on the intention of using technology does not cause respondents to exchange information on social media. The social media community is proven to affect e-WOM $\left(\mathrm{H}_{6}\right)$. The social media community positively enhanced e-WOM. The higher the use of the social media community, the more substantial the e-WOM. The findings supported by Choi et al., (2017) research that high social media use affects e-WOM because much information is transformed to other consumers in social media. For this reason, the high use of social media encourages the strengthening of e-WOM. Research by Seo, Park, and Choi (2020); Susanto and Keni (2018) also found that the social media community influences e-WOM because when consumers join a social media account, they will get notifications when other members share information.

Intention to use technology did not mediate the effect of ease of use on e-WOM $\left(\mathrm{H}_{7}\right)$ is rejected). Based on the results of testing the research hypothesis, it can be explained that the intention to use technology does not mediate the effect of ease of use on e-WOM. The intention to use technology has no impact on the effect of ease of use on e-WOM. The findings of this study are different from the research of Srivastava and Sharma (2017); Cataluna et al., (2014); state that the intention to use technology describes someone having the intention to use technology, and this desire will strengthen the effect of ease of use on e-WOM. Intention to use technology does not always have an impact on e-WOM, so that the intention to use this technology does not mediate the effect of ease of use on e-WOM.

The social media community mediates the effect of ease of use on e-WOM so that $\mathrm{H}_{8}$ is accepted. The social media community is proven to be able to strengthen the influence of ease of use on e-WOM. The results of testing the research hypothesis show that the social media community mediates the effect of ease of use on e-WOM. Communities on social media are motivated by the desire for mutual interaction between members so that their existence will strengthen the influence of ease of use on eWOM. E-WOM as a means of competing for interaction through communication shared on the social media community. The findings of this study are supported by Choi et al., (2017), Seo et al., (2020); Susanto and Keni (2018) stated that the community on social media is motivated by the desire to interact with fellow community members. When someone is driven by the desire to interact with each other, the ease of using technology encourages him to share information with fellow members of 
the social media community. For this reason, the community on social media will strengthen the influence of ease of use on e-WOM.

\section{Conclusion}

The primary goal of this study is to examine the effect of ease of use on e-WOM through intention to use technology and social media community in using mobile payments amid the COVID-19 era. Based on the results of the research and discussion, several conclusions were obtained. Ease of use of technology applications has a positive effect on the intention to use and e-WOM. This result shows the ease of operation of technology and ease of use and being proficient in using it has an impact on the intention to use technology and joining social media can provide comfort in using and feeling happy. Ease of use of technology applications has a positive effect on the social media community because of the ease of operation and understanding of the steps for using technology so that they can access and join as members and contribute to the social media community continuously. Intention to use in the technology and relatively low cost does not directly affect e-WOM but must go through a community on social media that provides an exciting atmosphere. Being accepted as a member of the Social media community and being happy in it and contributing to the community can have a significant effect on e-WOM. This finding shows that members of the social media community can share information on social media and share reviews among members, thereby creating a sense of trust and mutual concern among members. The increasing use of the social media community has made e-WOM stronger. This study may provide insight into the provider of the mobile payment application to consider the ease of use of the application in the pursuit of the increased number of application users. This study also enriches the current research in the field of technology application development.

\section{References}

Anita, T.L. (2019). The Effect of Perceived Quality in E-commerce to Customer Loyalty (WOM, INTENT, TRUST) Through Customer Satisfaction. Jurnal Hospitality dan Pariwisata, 4(1), 29-39.

Aydin, G., \& Burnaz, S. (2016). Adoption of mobile payment systems: A study on mobile wallets. Journal of Business, Economics, and Finance, 5(1), 73-92.

Basuki, R., Tarigan, Z.J.H., Siagian, H., Limanta, L.S., Setiawan, D. and Mochtar, J. (2022). The effects of perceived ease of use, usefulness, enjoyment and intention to use online platforms on behavioral intention in online movie watching during the pandemic era. International Journal of Data and Network Science, 6(1), 253-262, DOI: 10.5267/j.ijdns.2021.9.003

Cabosky, J. (2016). Social media opinion sharing: beyond volume. Journal of Consumer Marketing, 33(3), $172-181$.

Cataluna, F.J.R, Gaitan, J.A., \& Correa P.E.R. (2014). The relationship between e-WOM from SNS or internet and purchase. Business Science Reference, 1(1), 115-125.

Chinomona, R. (2013). The influence of perceived ease of use and perceived usefulness on trust and intention to use mobile social software. African Journal for Physical, Health Education, Recreation and Dance, 19(2), 258-273.

Choi, Y.K., Seo, Y. and Yoon, S. (2017). E-WOM messaging on social media: Social ties, temporal distance, and message concreteness. Internet Research, 27 (3), 495-505.

Chu, S.C., \& Kim, J. (2018). The current state of knowledge on electronic word-of-mouth in advertising research. International Journal of Advertising, 37(1), 1-13,

Correa, P.R., Grandón, E.E., Santana, M.R., \& Órdenes, L.B. (2019). Explaining the Use of Social Network Sites as Seen by Older Adults: The Enjoyment Component of a Hedonic Information System. International Journal of Environmental Research and Public Health, 16(10), 1-11.

Djalante, R., Lassa, J., Setiamarga, D., Sudjatma, A., Indrwan, M., and Haryanto, B. (2020). Review and analysis of current responses to COVID-19 in Indonesia: Period of January to March 2020. Progress in Disaster Science 6, 100091, http://dx.doi.org/10.1016/j.pdisas.2020.100091

Elsabeh, M.H., Zhao, Z., Ivens, B., \& Brem, A. (2019). When is brand content shared on Facebook? A field study on online Word-of-Mouth. International Journal of Market Research, 61(3), 287-301

Franciska, AM, \& Sahayaselvi, S. (2017). An overview of digital payments. International Journal of Research, 4(13), 21012111.

Hair, J.F., Risher, J.J., Sarstedt, M. and Ringle, C.M. (2019). When to use and how to report the results of PLS-SEM", European Business Review, 31(1), 2-24.

Hsu, L.C., Chih, W.H., \& Liou, D.K. (2016). Investigating community members' e-WOM effects on the Facebook fan page. Industrial Management \& Data Systems, 116(5), 978-1004

Kavitha, M. \& Kumar, K.S. (2018). A study on the digital payments system with the perspective of customer's adoption. Eurasian Journal of Analytical Chemistry, 13(1), 189-200

Kumar, V.V.R., Lall, A., \& Mane, T. (2017). Extending the TAM model: Intention of management students to use mobile banking: Evidence from India. Global Business Review, 18(1), 238-249

Liao, T.H. (2016). Sense of mobile virtual community (SOMVC): Measurement and integrated model. Journal of Information Management, 23(3), 335-376. 
Lok, C.K. (2015). Adoption of Smart Card-Based E-Payment System for Retailing in Hong Kong Using an Extended Technology Acceptance Model. E-services Adoption: Processes by Firms in Developing Nations (Advances in Business Marketing and Purchasing, Vol. 23B), Emerald Group Publishing Limited, 255-466.

López, M. and Sicilia, M. (2013). How WOM marketing contributes to new product adoption: Testing competitive communication strategies. European Journal of Marketing, 47(7), 089-1114.

López, M. \& Sicilia, M. (2014). Determinants of e-WOM influence: The role of consumers' internet experience. Journal of Theoretical and Applied Electronic Commerce Research, 9(1), 28- 43.

Mensah, I.K. (2010). Perceived usefulness and ease of use of mobile government services: The moderating impact of electronic word of mouth (eWOM). International Journal of Technology Diffusion, 11(1), 1-16.

World Health Organization (WHO). (2020). Five ways to protect health workers during the COVID-19 crisis, https://iloblog.org/2020/04/01/five-ways-toprotect-health-workers-during-the-COVID19-crisis/ (August 06, 2020).

Sahin, I., Gulmez, M., \& Ersoy, E. (2019). Social media marketing and e-WOM: Young consumers' online brand-related activities, attitudes, and engagement. Journal of Internet Application and Management. 10(1), 5 - 24.

Sathye, S., Prasad, B., Sharma, D., Sharma, P., \& Sathye, M. (2016). Factors influencing the intention to use mobile valueadded services by women-owned micro-enterprises in Fiji. Electronic Journal Information System Development Countries, 1(1), 1-10.

Seo, E, J., Park, J.W., \& Choi, Y.J. (2020). The effect of social media usage characteristics on e-WOM, trust, and brand equity: Focusing on users of airline social media, Sustainability, 12(1691), 1-18.

Shaw, B., \& Kesharwani, A. (2019). Moderating effect of smartphone addiction on mobile wallet payment adoption. Journal of Internet Commerce, 18(3), 291-309

Srivastava, D., \& Sharma, R.W. (2017). Developing a model for studying the antecedents and effects of word of mouth (WoM) and e-WoM marketing based on literature review. Jindal Journal of Business Research, 6(1), 25-43

Susanto, W.K., \& Keni (2018). The effect of social network marketing (SNM) and electronic word of mouth (e-WOM) on customer's buying interest. Jurnal Manajemen Bisnis dan Kewirausahaan, 2(6), 68-73.

Tarigan, Z.J.H., Basuki, R., \& Siagian, H. (2020). The impact of information technology quality on electronic customer satisfaction in movie industry. International Journal of Data and Network Sciences, 4(3), 263-270.

Tarigan, Z.J.H., Jiputra, J.A., and Siagian, H. (2021). The effect of supply chain practices on retailer performance with information technology as moderating variable. International Journal of Data and Network Science, 5(1), 47-54, doi: $10.5267 / j . i j d n s .2020 .11 .003$

Tarigan, Z.J.H., Sutapa, I.N., Mochtar, J. \& Suprapto, W. (2019). Measuring Teachers' Competency in Determining Students' Satisfaction through Electronic Internet Survey Method. International Journal of Information and Education Technology, 9, (3), 236-240

Teoh, W. M.-Y., Chong, S.C., Lin, B. and Chua, J.W. (2013). Factors affecting consumers' perception of electronic payment: an empirical analysis. Internet Research, 23 (4), 465-485

Terenina I.V., Ovanesyan N.M., Khan R.S., \& Fedosenko A.A. (2019). Marketing Activity in the Context of the Digital Economy. International Journal of Economics and Business Administration, VII, (s1), 16-25

Thirupathi, M., Vinayagamoorthi, G., \& Mathiraj, S.P. (2019). Effect Of cashless payment methods: A case study perspective analysis. International Journal of Scientific \& Technology Research, 8(8), 394- 397.

Vohra, A. and Bhardwaj, N. (2019). Customer engagement in an e-commerce brand community: An empirical comparison of alternate models. Journal of Research in Interactive Marketing, 13(1), 2-25.

Voorveld, H.A.M., Noort, G.V., Muntinga, D.G., \& Bronner, F. (2018). Engagement with social media and social media advertising: The differentiating role of platform type. Journal of Advertising, 47(1), 1-17.

Wirtz, B.W., \& Gottel, V. (2016). Technology acceptance media: Review, synthesis, and directions for future empirical research. Journal of Electronic Commerce Research, 17(2), 97 - 115.

Yalcin, M.E., \& Kutlu, B. (2019). Examination of students' acceptance of and intention to use learning management systems using extended TAM. British Journal of Educational Technology, 50(5), 2414-2432

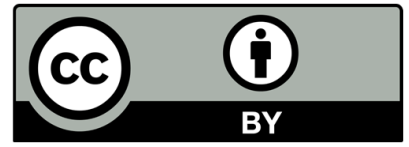

(C) 2022 by the authors; licensee Growing Science, Canada. This is an open access article distributed under the terms and conditions of the Creative Commons Attribution (CC-BY) license (http://creativecommons.org/licenses/by/4.0/). 